\title{
MODEL STRATEGI KEMITRAAN PADA LEMBAGA PENDIDIKAN ISLAM (STUDI KASUS DI MAN 2 MATARAM)
}

\author{
S. Ali Jadid Al Idrus ${ }^{1}$ \\ UIN Mataram \\ s.alijadid75@gmail.com
}

\begin{abstract}
Abstrak: Pendidikan merupakan kebutuhan yang sangat penting dalam kehidupan manusia, juga sebagai sasaran utama upaya pembangunan manusia. Pendidikan diyakini mampu mengubah pola pikir masyarakat yang nantinya diharapkan membawa perubahan bagi bangsanya. Setiap lembaga atau organisasi sosial, khususnya sekolah/madrasah dalam melaksanakan aktivitas selalu berkaitan dengan usaha mengembangkan kerja sama satu kesatuan, dengan memanfaatkan sumber daya yang ada guna mencapai tujuan tertentu dalam organisasi yang telah ditetapkan sebelumnya (pre determine objective).. Untuk memudahkan dalam mencari data atau informasi yang terkait dengan kajian ini, maka perlu membatasi masalah. Kajian akan fokus pada proses, visualisasi, konstruksi dan tujuan membagun keunggulan bersaing di MAN 2. Dan lebih khusus adalah tentang bagaimana analisis lingkungan, bagaimana akuntabillitas lembaga, dan bagaimana bentuk kerjasama lembaga dengan masyarakat baik masyarakat sekitar maupun masyarakat luas pada umumnya. Kajian ini diharapkan dapat berkonstribusi pada; (1) menambah dan memperkaya khazanah keilmuan pendidikan khususnya manajemen pendidikan Islam dalam mengaplikasikan bagaimana strategi kemitraan dalam membangun keunggulan bersaing guna menciptakan lembaga pendidikan yang bermartabat dan berdaya saing dalam rangka mengembangkan dan memajukan pendidikan. (2) Bagi para pembuat dan pengambil kebijakan sebagai salah satu acuan terkait dengan strategi kemitraan dalam membangun keunggulan bersaing pada lembaga pendidikan guna mengembangkan dunia pendidikan Islam formal maupun non formal, (3) Bagi para pelaksana kebijakan pendidikan dalam mensosialisasikan dan menanamkan nilai-nilai kebersamaan guna membangun dunia pendidikan dan lembaga pendidikan dengan menerapkan strategi kemitraan dalam membangun keunggulan bersaing di lembaga pendidikan Islam. Bagi para peneliti lainnya sebagai bahan acuan dalam melaksanakan penelitian selanjutnya terutama tentang strategi lembaga pendidikan Islam.
\end{abstract}

Kata kunci; Menumbuhkan, Keunggulang, Bersaing, Lembaga, Pendidikan Islam

${ }^{1}$ Lektor Kepala pada Mata Kuliah Manajemen Pendidikan pada Prodi S2 Manajemen Pendidikan Islam dan Wakil Dekan Bidang Kemahasiswaan, Alumni dan Kerjasama Fakultas Usuluddin dan Studi Agama Universitas Islam Negeri Mataram. s.alijadid75@gmail.com 


\section{A. Pendahulun}

Pendidikan Islam seringkali dikesankan sebagai pendidikan yang tradisional dan konservatif. Menurut pengamatan Amin Abdullah, bahwa kebanyakan pendidikan Islam masih menggunakan pola konvensional-tradisional, tidak saja yang terjadi di lembaga pendidikan non formal seperti pondok pesantren dan madrasah diniyah, akan tetapi juga di sekolah Islam, madrasah dan perguruan tinggi. ${ }^{2}$ Pandangan tersebut lumrah dan wajar karena orang memandang bahwa kegiatan pendidikan Islam dihinggapi oleh lemahnya penggunaan metodelogis pembelajaran yang cenderung tidak menarik perhatian dan memberdayakan. Oleh karena itu, pelaksanaan pendidikan Islam akan relevan serta harus dicari terobosan baru dan inovasi yang relevan dengan zaman, sehingga isi dan metodologi pendidikan Islam menjadi aktual-kontekstual.

Memasuki millennium ke tiga lembaga pendidikan memiliki dua dimensi yang erat berkaitan yaitu lokalisme dan globalisme artinya tidak terlepas dari analisis mengenai dimensi lokal dan kemudian sejalan dengan mengembangkan dimensi global. Membangun lembaga pendidikan pada kehidupan global harus memperbaiki mutu dan kelembagaan. Menurut pandangan Tilaar, pada dimensi lokal visi pendidikan mempunyai unsur-unsur sebagai berikut; (1) akuntabilitas, (2) relevansi, (3) kualitas, (4) otonomi kelembagaan, dan (5) jaringan kerja sama. Pada dimensi global visi lembaga pendidikan mempunyai tiga aspek yaitu; (1) kompetitif, (2) kualitas, dan (3) jaringan kerja sama. ${ }^{3}$ Berdasarkan kondisi tersebut, maka perlu pengkajian tentang bagaimana strategi yang digunakan oleh Madrasah sebagai lembaga pendidikan Islam dalam membangun Keunggulan Bersaing

Madrasah sebagai salah satu lembaga pendidikan yang berperan membentuk sumber daya pembangunan yang berada di bawah Kementrian Agama Republik

2 Amin Abdullah, Studi Agama, Normativitas atau Historias, (Jogyakarta: Pustaka Pelajar, 1996), 67.

${ }^{3}$ H. A. R. Tilaar, Paradigma baru Pendidikan nasional, (Jakarta: Rineka cipta, 2000), 110. 
Indonesia, tengah berupaya melakukan berbagai program strategis agar tidak tertinggal dengan kemajuan perkembangan lembaga pendidikan lainnya. Pada tataran lokal dimensi visi pendidikan dapat dijelaskan sebagai berikut:

Tabel. 1

Proses Strategi Kemitraan di MAN 2 Mataram $^{4}$

\begin{tabular}{|l|l|l|l|}
\hline No & Proses Visualisasi & \multicolumn{1}{|c|}{ Uraian } & Ket \\
\hline 1 & Akuntabilitas & $\begin{array}{l}\text { Bermakna berbasis kebutuhan masyarakat, } \\
\text { partisipasi dalam pengelolaan dan merasa } \\
\text { memiliki }\end{array}$ & \\
\hline 2 & Relevansi & $\begin{array}{l}\text { Memiliki program nyata sesuai kebutuhan } \\
\text { dunia luar, industri, ilmu pengetahuan, } \\
\text { tekhnologi, keterampilan, budaya, moral, } \\
\text { etika, dan agama }\end{array}$ & \\
\hline 3 & Kualitas & $\begin{array}{l}\text { Penggerak mutu pendidikan yang didukung } \\
\text { sarana prasarana, SDM, dan manajerial } \\
\text { berkualitas. }\end{array}$ & \\
\hline 4 & $\begin{array}{l}\text { Otonomi } \\
\text { Kelembagaan }\end{array}$ & $\begin{array}{l}\text { Pelopor perubahan, berprestasi, serta } \\
\text { otonomi dalam manajemen, penyusunan } \\
\text { program, dan budget. }\end{array}$ & \\
\hline
\end{tabular}

Tujuan diselenggarakannya proses pendidikan adalah menciptakan dan mengembangkan persepsi terbaik bagi suatu lembaga, organisasi terhadap segmen masyarakat yang kegiatannya langsung ataupun tidak langsung mempunyai dampak bagi masa depan sekolah/madrasah. Desentralisasi pendidikan mengacu pada konsep: (1) Desentralisasi pemerintahan di bidang pendidikan, dengan terwujudnya pemerintahan daerah yang otonom dalam pengelolaan pendidikan, (2) Desentralisasi pada satuan pendidikan, dengan terwujudnya lembaga atau satuan pendidikan yang mandiri dan professional, (3) Desentralisasi pada stakeholders pendidikan, dengan terwujudnya masyarakat yang demokratis dan lembaga yang peduli pendidikan secara mandiri dan profesional. ${ }^{5}$ Madrasah merupakan salah satu lembaga pendidikan hasil bentukan lembaga-lembaga keagamaan atau kelompok

4 Observasi, proses kemitraan di MAN 2 Mataram, tanggal 3 Juli 2017

${ }^{5} \mathrm{Mada}$ Sutapa, Perspektif Desentralisasi Pendidikan dalam Konteks Desentralisasi Pemerintahan, Jurnal Manajemen Pendidikan, No. 01, Oktober, 2005. 
masyarakat yang bertujuan untuk melahirkan lembaga pendidikan yang mengintegrasikan pembelajaran mata pelajaran umum (seperti fisika, biologi, kimia, dsb) dengan mata pelajaran agama Islam dalam kegiatan.

Usaha pemerintah untuk mengoptimalkan hasil pendidikan di mana sebuah strategi menjadi sangat penting untuk dilaksanakan, maka dalam usia yang mendekati dewasa MAN 2 Mataram terus bergerak dengan semangat progresif, terbukti dengan berbagai kemajuan yang diperoleh selama ini, sehingga MAN 2 disamping berstatus Madrasah Model dari SK Depag RI, Kakanwil Kementerian Agama Propinsi Nusa Tenggara Barat juga memberikan status Madrasah Aliyah Unggulan di Provinsi Nusa Tenggara Barat. Bahkan dengan progres MAN 2 yang semakin maju, dalam proses akreditasi terakhir tahun 2010, MAN 2 mendapatkan nilai akreditasi $\mathrm{A}^{+}$dari Badan Akreditasi Nasional (BAN) Jakarta. ${ }^{6}$

Sesuai dengan uraian pada pendahuluan, maka permasalahan yang timbul dapat diidentifikasikan sebagai berikut: (1) Strategi yang digunakan masih dianggap kurang integratif, sehingga pemimpin seharusnya memiliki sebuah rumusan agar strategi yang dilaksanakan dapat diwujudkan sesuai dengan tujuan yang diharapkan, (2) Kemitraan yang terealisasi dilapangan belum maksimal saling menguntungkan antar pihak, dengan menempatkan kedua pihak dalam posisi sederajat., (3) Perencanaan Partisipatori belum efektif pelaksanaannya karena hanya melibatkan pihak yang berkepentingan terhadap pembangunan saja, (4) Partisipasi Masyarakat yang masih kurang dalam hal interaksi sosial dengan pihak sekolah, dimana dalarn proses pengambilan keputusan atau pelaksanaan program tidak ada keterlibatan yang terwujud sehingga tidak ada keberlangsungan program yang relatif terjamin. Karena tidak ada keterlibatan masyarakat sehingga tidak dapat menumbuhkan keyakinan kolektif sebagai suatu yang dapat mendorong harapan-harapan yang kita yakini sehingga benar-benar tercapai (self-fulling propechy) keberhasilan program.

${ }^{6}$ Dokumentasi, Sejarah Lahirnya MAN 2 Mataram, 20 Januari 2017. 
S. Ali Jadid

\section{B. Pembahasan}

\section{Proses Kemitraan di MAN 2 Mataram}

Substansi dari kemitraan dimaknai sebagai upaya untuk mengedepankan pentingnya pemahaman bersama terhadap masalah dan peran dari masyarakat, instansi/lembaga, organisasi yang menjadi mitra MAN 2 Mataram. Untuk menghindari adanya ketidakfahaman para mitra kerja tentang masalah-masalah yang ditemui selama proses pelaksanaan program-program yang ada. Strategi kemitraan MAN 2 digunakan dalam rangka mengupayakan keunggulan dan kualitas pendidikan, karena kemitraan telah dianjurkan pemerintah sejak lama, sesuai dengan Peraturan Pemerintah Nomor 44 Tahun 1997. Definisi dari kemitraan telah tertuang pula dalam Undang-undang Nomor 9 Tahun 1995 yang berbunyi, "bahwa kemitraan adalah kerjasama antara usaha kecil dengan usaha menengah atau dengan usaha besar disertai pembinaan dan pengembangan oleh usaha menengah atau usaha besar dengan prinsip saling memerlukan, saling memperkuat dan saling menguntungkan".

Dalam "The American Heritage Dictionary"(kamus warisan milik Amerika), kemitraan (partnership) didefinisikan sebagai : "a relationship between individuals or group that is characterized by mutual cooperation and responsibility, as for the achievement of a specified goals" (hubungan antara individu dan kelompok yang ditandai dengan kerjasama dan tanggung jawab demi tercapainya tujuan yang telah ditentukan). Dalam hal ini Wood and Gray mengemukakan: "The partnership must, however, develop a shared purpose, with a common understanding of the problem and the role of each organization in addressing the problem" (namun demikian hubungan kerjasama tersebut harus didasari atas tujuan bersama dengan pemahaman masalah dan peran organisasi masing-masing dalam pemecahan masalah tersebut). ${ }^{7}$

Kay W. Eillbert mengemukakan pentingnya motivasi dibangun oleh masingmasing institusi atau perorangan yang bermitra, sebagaimana pendapatnya "Motivation must explicit for joining a partnership, allowing for discussion of differences and development of ways

\footnotetext{
${ }^{7}$ Nana Rukmana D.W., Strategic Partnering For Educational Management, (IKAPI: Alfabeta, 2006), 59.
} 
to accommodate any differences"(motivasi harus nampak saat menetapkan kerjasama yang memungkinkan diskusi perbedaan-perbedaan dan pengembangan cara-cara mengakomodasi perbedaan-perbedaan tersebut). Lebih jauh Kay W. Eillbert mengemukakan: "Organizational motivations provide further explanation for the increasing interest in partnership"(motivasi organisasi memberi penjelasan lanjut atas ketertarikan yang lebih tinggi pada partnership/kerjasama). ${ }^{8}$

Penerapan dan pelaksanaan kemitraan senantiasa melakukan langkah-langkah yang pastinya mendapat respon sangat maksimal dari para calon mitra kerja. Dengan langkah-langkah yang telah dipaparkan sebelumnya, maka MAN 2 Mataram mendapatkan banyak relasi hubungan kemitraan yang telah terjalin dalam jangka waktu yang bisa dikatakan panjang, mulai dari 1 (satu) tahun sampai 3 (tiga) tahun. Strategi kemitraan MAN 2 Mataram adalah suatu sikap menjalankan kerjasama yang bisa dikatakan bercirikan hubungan jangka panjang, formal, dan juga merupakan suatu kerjasama tingkat tinggi, yang saling percaya, terbuka, dan tentunya saling memberi keuntungan dalam mencapai tujuan dari hubungan kerja kemitraan. Kemitraan yang diharapkan MAN 2 Mataram bukanlah kemitraan yang bebas nilai, melainkan kemitraan yang tetap dilandasi oleh tanggung jawab moral dan etika kerjasama yang sehat, yang sesuai dengan demokrasi pendidikan. ${ }^{9}$

Menurut Sentanoe Kertonegoro dalam Nana, kemitraan adalah kerjasama yang saling menguntungkan antar pihak, dengan menempatkan kedua pihak dalam posisi sederajat. ${ }^{10}$ Dalam kemitraan ini mengandung pengertian kegiatan kerjasama yaitu derajat upaya suatu pihak untuk memenuhi keinginan pihak lain. Keteguhan, yaitu derajat upaya sesuatu pihak untuk memenuhi keinginannya sendiri. Kolaborasi, yaitu situasi di mana masing-masing pihak dalam konflik ini bersedia mengorbankan sesuatu, sehingga terjadi pembagian beban dan manfaat. Mengakomodasi yaitu kesediaan salah satu pihak dalam konflik untuk menempatkan kepentingan lawannya di atas kepentingannya sendiri.

Kemitraan tentunya akan memberikan keuntungan yang lebih besar dalam jangka panjang, karena tidak harus mengalokasikan dana investasi yang

\footnotetext{
${ }^{8}$ Nana Rukmana D.W., Strategic Partnering For Educational Management, (IKAPI: Alfabeta, 2006), 59.

${ }^{9}$ Wawancara. Proses Kemitraan di MAN 2 Mataram. KM. 5 Juli 2017

${ }^{10}$ Nana Rukmana D.W., Strategic Partnering For Educational Management, (IKAPI: Alfabeta, 2006), 60.
} 
besar untuk membangun dan mengoperasikan sarana dan prasarana pendidikan. Oleh karena itu dengan kemitraan ini akan ada sesuatu yang berubah dalam pengelolaan pendidikan, yang diharapkan dapat memberikan manfaat yang besar. Substansi dari kemitraan yang dijalankan oleh MAN 2 Mataram tidak hanya berupa kerjasama formal belaka. Sebab, dalam kemitraan itu mengandung proses-proses yang dibangun sebelum, sesaat kemitraan berlangsung, sampai setelah periode kerjasama disepakati para pihak. Lebih dari itu, kemitraan juga tidak dapat dilepaskan begitu saja dari kompromi, kolaborasi, dan akomodasi jika terjadi konflik di antara para pihak yang terlibat konflik kepentingan. Prinsip tersebut didasari oleh adanya kesediaan dari salah satu pihak yang berkonflik untuk menempatkan kepentingan lawannya di atas kepentingannya sendiri ${ }^{11}$.

Beberapa bentuk implementasi yang berkaitan dengan peningkatan sumber daya dari hubungan kemitraan yang terjalin, bukan hanya sumber daya bagi para guru dan pegawai saja yang mendapatkan banyak manfaat dari hubungan kemitraan yang dijalin MAN 2 Mataram bersama para mitra kerja. Mulai dari pembinaan sampai kepada peningkatan kualitas akademik siswa-siswi. Kemitraan di MAN 2 Mataram, dapat diidentifikasi melalui beberapa aspek antara lain model, pola dan tujuan sebagaimana tabel berikut ini;

Tabel.2

Model, Pola, Tujuan Proses Kemitraan di MAN 2 Mataram $^{12}$

\begin{tabular}{|c|c|c|c|c|}
\hline No & Model & Pola & Tujuan & Ket \\
\hline 1 & Keunggulan & $\begin{array}{l}\text { Kerjasama dengan } \\
\text { pelanggan }\end{array}$ & Saling Menguntungkan & \\
\hline 2 & Kualitas & $\begin{array}{l}\text { Kerjasama dengan } \\
\text { pemasok }\end{array}$ & $\begin{array}{l}\text { Tercapainya tujuan } \\
\text { khusus }\end{array}$ & \\
\hline 3 & Berdaya saing & $\begin{array}{l}\text { Kerjasama dalam } \\
\text { Pemanfaatan } \\
\text { sumberdaya } \\
\text { kemitraan }\end{array}$ & kebersamaan & \\
\hline 3 & Berkelanjutan & $\begin{array}{l}\text { Kerjasama dalam } \\
\text { pengembangan }\end{array}$ & Kepercayaan & \\
\hline
\end{tabular}

11 Wawancara. Proses Kemitraan di MAN 2 Mataram. WKM. 5 Juli 2017

12 Observasi. Proses Kemitraan di MAN 2 Mataram. 5 Juli 2017 
Bentuk akademik sumber daya yang positif bagi siswa adalah memberikan bimbingan belajar kepada peserta didik MAN 2 Mataram, khususnya dalam menghadapi ujian akhir sekolah. Ganesha Opertion (GO) Lombok juga memberikan trik-trik dan metode-metode mengerjakan soal-soal serta tehnik penyelesainnya yang tentunya dengan hasil tepat dan benar. Hal-hal tersebut merupakan bentuk-bentuk dari kepercayaan yang telah diberikan oleh para mitra kerja. Begitu pula Museum Nusa Tenggara Barat, yang selalu bersedia memberikan tempat dan kesempatan bagi para siswa siswi yang ingin lebih mengenal bagaimana sejarah dan asal usul adat istiadat serta kebiasaan yang ada di Nusa Tenggara Barat, ataupun benda-benda bersejarah yang menjadi peninggalan pada zaman terdahulu. Dalam kegiatan kunjungan di Museum mereka mengamati dan mencatat pula berbagai bentuk produk budaya masa lampau. Kegiatan kunjungan ke Museum Nusa Tenggara Barat ini berlangsung di detiap tahun pelajaran.

\section{Visualisasi}

Visualisasi merupakan gambaran informasi tentang suatu gagasan dengan menggunakan gambar. Dalam hal ini MAN 2 Mataram membuat papan pengumuman terkait dengan informasi yang berhubungan dengan MAN 2 Mataram. Misalnya adalah data statistik angka siswa/siswa pertahunnya, jumlah lulusan pertahunnya, indeks prestasi siswa yang dicapai pertahunnya, jumlah guru dan pegawai TU, dan lain sebagainya ${ }^{13}$. Perencanaan ini biasanya diambil oleh pucuk pimpinan (kepala sekolah/madrasah) yang kadang kurang didukung oleh data-data statistik tetapi lebih kepada pertimbangan perencanaan. Menurut pendapat Achmad Sanusi visi atau wawasan adalah penglihatan yang mendalam yang mengandung pengetahuan (cognittif), kecintaan (afektif), dan kepedulian terhadap profesi serta kemampuan (konatif). ${ }^{14}$

Penerapan strategi kemitraan di MAN 2 Mataram, saling percaya, terbuka serta adanya keuntungan diantara kedua pihak dari hasil hubungan

13 Observasi. Visualisasi di MAN 2 Mataram. 6 Juli 2017

14 Sanusi Achmad \& Rochman Natawidjaja, Studi Pengembangan Model Pendidikan Profesional Tenaga Kependidikan, (Jakarta: Depdikbud, 1991), 10. 
kemitraan yang dilakukan dengan para mitra kerja strategi kemitraan bukanlah penguasaan yang satu atas yang lain, khususnya yang besar atas yang kecil, melainkan menjamin kemandirian pihak-pihak yang bermitra, karena bermitra bukanlah merger atau akuisi. Sebagai salah satu institusi atau lembaga yang menjalin hubungan kemitraan, MAN 2 Mataram perlu mengembangkan konsep bersama dengan mitra kerja berupa visi, misi, tujuan, rencana strategik serta indikator kerja. Dalam hubungan kemitraan pendidikan misalnya harus secara bersama-sama menetapkan indikator kerja (performance indicators) dalam setiap "building block" yakni input, transformasi, output, dan outcome. ${ }^{15}$

Pada kenyataannya, implementasi strategi tidak mudah dilakukan. Dari tiga elemen strategik, yaitu analisis strategi, formulasi strategi, dan implementasi strategi, yang paling sulit untuk dilakukan adalah implementasi strategi. Sebagaimana diungkapkan oleh Miller: "It has been rather easy for us to decide where we wanted to go. The hard part is to get the organization to act on the new priorities" (karenanya sekarang nampak lebih mudah untuk menentukan arah tujuan organisasi.

Berdasarkan observasi yang dilakukan, maka ditemukan bahwa strategi kemitraan yang dijalankan oleh MAN 2 Mataram adalah berangkat dari visi, dan misi madrasah. Dengan visi; Terwujudnya Madrasah yang melahirkan generasi Islami, Inovatif, Berprestasi, dan Populis. Dan dengan adanya visi yang singkat padat namun berisi, tercetus pulalah rangkaian-rangkaian misi dari sebuah organisasi atau lembaga, apalagi sebuah madrasah, yang begitu penuh dengan pertimbangan sebelum akhirnya tertuang dalam sebuah misi madrasah sebagai alasan dari eksistensi MAN 2 Mataram.

Tabel. 3

Visualisasi Kemitraan di MAN 2 Mataram

\begin{tabular}{|l|l|l|c|}
\hline NO & \multicolumn{1}{|c|}{ Uraian } & \multicolumn{1}{|c|}{ Bentuk } & Ket \\
\hline 1 & $\begin{array}{l}\text { menumbuhkan pemahaman dan } \\
\text { pengamalan nilai-nilai ajaran agama } \\
\text { bagi warga madrasah }\end{array}$ & $\begin{array}{l}\text { spiritualitas, nilai moralitas, } \\
\text { dan nilai sosial. }\end{array}$ & \\
\hline 2 & $\begin{array}{l}\text { yang menguasai ilmu pengetahuan } \\
\text { dan teknologi berlandaskan iman } \\
\text { dan taqwa }\end{array}$ & $\begin{array}{l}\text { menguasai } \\
\begin{array}{l}\text { Pengetahuan Alam (IPA), } \\
\text { Ilmu Pengetahuan Sosial } \\
\text { (IPS), dan Bahasa Asing }\end{array}\end{array}$ & \\
\hline
\end{tabular}

15 Wawancara. Visualisasi di MAN 2 Mataram. KMT. 7 Juli 2017 


\begin{tabular}{|c|c|c|}
\hline & & $\begin{array}{l}\text { seperti Bahasa Arab dan } \\
\text { Bahasa Inggris serta Ilmu- } \\
\text { ilmu Agama baik yang } \\
\text { berkaitan dengan Fiqih, } \\
\text { Tauhid, dan Sejarah } \\
\text { Kebudayaan Islam }\end{array}$ \\
\hline 3 & $\begin{array}{l}\text { membudayakan lingkungan belajar } \\
\text { dan bekerja yang berorientasi pada } \\
\text { perubahan }\end{array}$ & $\begin{array}{lr}\text { mencetak warga madrasah } \\
\text { yang berdaya saing dalam } \\
\text { era global; } & \text { seperti } \\
\text { malakukan mitra } & \text { kerja } \\
\text { dengan pihak } & \text { eksternal } \\
\text { seperti pihak } & \text { Swasta } \\
\text { maupun negeri } & \end{array}$ \\
\hline 4 & $\begin{array}{l}\text { mewujudkan madrasah yang } \\
\text { mampu memberikan pelayanan } \\
\text { terbaik kepada semua lapisan } \\
\text { masyarakat }\end{array}$ & $\begin{array}{l}\text { memberikan rasa } \\
\text { kenyamanan bagi warga } \\
\text { sekitar madrasah baik yang } \\
\text { berupa instansi maupun } \\
\text { non instansi }\end{array}$ \\
\hline
\end{tabular}

Bagian paling susah adalah membuat organisasi bertindak pada prioritasprioritas yang baru). ${ }^{16}$ Perencanaan Strategis (Restra) merupakan langkah awal yang dilakukan oleh MAN 2 Mataram agar mampu menjawab segala tuntutan lingkungan strategis baik lokal, regional, nasional dengan tetap berada dalam tatanan sistem administrasi Negara Kesatuan Republik Indonesia, melalui pendekatan yang jelas dan sinergi, maka MAN 2 Mataram dapat menyelaraskan visi dan misinya. Strategi kemitraan mulai bergairah dalam rangka memompa sumber daya manusia agar lebih berkualitas, telah menjadi proyek besar yang melibatkan hampir semua lembaga pendidikan di Indonesia termasuk madrasah. Kemitraan yang saling menguntungkan antar pihak dengan menempatkan kedua pihak dalam posisi yang sederajat.

Rencana strategis sangat menentukan langkah-langkah dan tindakan yang akan diambil MAN 2 Mataram untuk mencapai tujuan strategis. Tujuan rencana strategis adalah mewujudkan tujuan lembaga dalam tenggang waktu atau periode yang telah ditetapkan. Perencanaan strategis berkaitan dengan kegiatan menetapkan

${ }^{16}$ A. Miller dan G. Dess, G. Strategic Manjemen, (New York: McRaw Hill Companies, 1996), 329. 
S. Ali Jadid

tujuan, pengalokasian sumber-sumber untuk mencapai tujuan sekolah. ${ }^{17}$ Demikianlah visualisasi di MAN 2 Mataram. Visi diterjemahkan di dalam misi selanjutnya perlu diwujudkan di dalam program-program pengembangan baik jangka pendek maupun jangka panjang. Di dalam mewujudkan visi dan misi tersebut tentunya akan menghadapi berbagai hambatan dan tantangan. Oleh karena itu kemampuan dan kreativitas dari pimpinan lembaga pendidikan sangat dipertaruhkan.

\section{Konstruksi}

Pendidikan sebagai suatu proses, memerlukan suatu strategi pengelolaan tertentu, yang sering pula dikenal sebagai Administrasi Pendidikan atau Manajemen Pendidikan. Walaupun dalam prakteknya belum ada kesepakatan mengenai persamaan atau perbedaan pengertian kedua istilah tersebut, namun dapat dikatakan bahwa administrasi pendidikan "sejajar" pengertiannya dengan Manajemen Pendidikan. Strategi kemitraan di MAN 2 Mataram, merupakan proses dari berbagai kegiatan yang dilakukan secara menyeluruh dalam berbagai usaha yang tujuannya adalah untuk mencapai hasil yang optimal. Ruang lingkup strategi kemitraan di MAN 2 Mataram, meliputi kegiatan perencanaan, pelaksanaan, dan pengawasan untuk mencapai produktivitas tujuan pendidikan. ${ }^{18}$

Tilaar dalam bukunya Pendidikan Nasional yang menggambarkan tiga unsur proses manajemen, yaitu perencanaan, pelaksanaan, dan pengawasan dalam rangka mencapai tujuan pendidikan dengan memanfaatkan secara efektif dan efisien sumber daya yang dimiliki berupa manusia, keuangan, fisik, maupun informasi berupa pengetahuan. Hal senada diungkapkan oleh Nanang Fatah bahwa dalam proses manajemen, fungsi-fungsi pokok yang ditampilkan oleh seorang manajer/pimpinan meliputi planning, organizing, leading, dan controlling sehingga manajemen diartikan sebagai proses merencana, mengorganisasi, memimpin, dan

\footnotetext{
17 St. Rodliyah, Partisipasi Masyarakat Dalam Pengambilan Keputusan dan Perencanaan Di Sekolah, (Jogyakarta: Pustaka Pelajar dan STAIN Jember Press, 2013), 104.

18 Observasi. Konstruksi Kemitraan di MAN 2 Mataram. 7 Juli 2017.
} 
mengendalikan upaya organisasi dengan segala aspeknya agar tujuan organisasi tercapai seacara efektif dan efisien.

Pelanggan lembaga pendidikan terdiri dari pelanggan primer yakni peserta didik atau pihak yang menerima jasa pendidikan secara langsung, pelanggan skunder yaitu pihak yang berkepentingan terhadap mutu jasa pendidikan, yaitu orang tua, instansi/sponsor peserta didik, dan pemerintah, para pengelola pendidikan ( tenaga kependidikan dan administrasi), pelanggan tersier, yaitu khusus dunia usaha dan pemerintah, karena mereka membutuhkan sumber daya manusia terdidik dan terampil untuk pembangunan. Pengelola pendidikan yang terdiri dari pimpinan lembaga, tenaga kependidikan dan tenaga administrasi. ${ }^{19}$

Proses implementasi strategi meliputi keseluruhan kegiatan manajerial yang mencakup keadaan seperti motivasi, kompensasi, penghargaan manajemen, dan proses pengawasan, implementasi dicapai melalui semacam alat administrasi yang dapat dikelompokkan ke dalam tiga kategori yaitu struktur, proses, dan tingkah laku. $^{20}$ Kemitraan mementingkan adanya beberapa tindakan utama yang pada dasarnya mengkombinasikan beberapa unsur yang menjadi perekatnya, antara lain: 1) kerjasama; 2) keteguhan; 3) kolaborasi; 4) kompromi; dan 5) akomodasi. Kerjasama atau kemitraan merupakan keinginan suatu pihak untuk memenuhi keinginan pihak lain. Sebaliknya, keteguhan berarti keinginan suatu pihak untuk memenuhi keinginannya sendiri.

Tabel. 4

Konstruksi Kemitraan di MAN 2 Mataram

\begin{tabular}{|c|c|c|c|}
\hline $\mathrm{NO}$ & Uraian & Bentuk & Ket \\
\hline 1 & 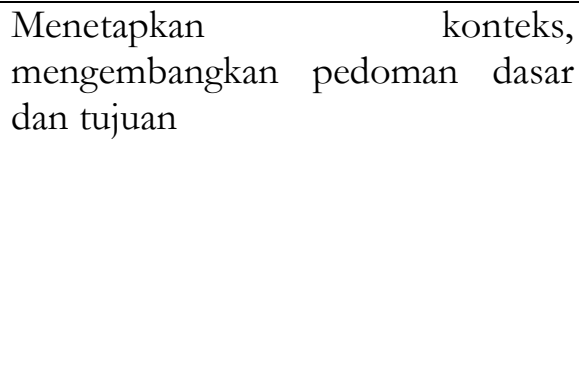 & $\begin{array}{l}\text { - Kamad yang } \\
\text { merencanakan konstruksi } \\
\text { administrasi lembaga } \\
\text { - Kamad mementukan } \\
\text { konteks dan } \\
\text { mengembangkan dasar } \\
\text { juga tujuan yang akan } \\
\text { digunakan dalam }\end{array}$ & \\
\hline
\end{tabular}

19 Wawancara. Konstruksi Kemitraan di MAN 2 Mataram. KM. 7 Juli 2017

${ }^{20}$ Dan Schendel dan Charles Hofer, Higgins, Pengambilan Keputusan Stratejik. Untuk Organisasi Public dan Organisasi Non Profit, (Jakarta: Grasindo,1985), 145. 


\begin{tabular}{|c|c|c|}
\hline & & pengambilan keputusan \\
\hline 2 & $\begin{array}{ll}\text { Mengidentifikasi } & \text { dan } \\
\text { memprioritaskan peluang } & \end{array}$ & $\begin{array}{lr}\text { Meningkatkan } & \text { dan } \\
\text { mewujudkan kemenangan } \\
\text { dengan cepat }\end{array}$ \\
\hline 3 & $\begin{array}{l}\text { Merencanakan dan mengenalkan } \\
\text { program }\end{array}$ & $\begin{array}{l}\text { Membuat rencana dan } \\
\text { bagaimana mengenalkan } \\
\text { program kepada para mitra }\end{array}$ \\
\hline 4 & $\begin{array}{l}\text { Meningkatkan kesepakatan pada } \\
\text { model bisnis }\end{array}$ & $\begin{array}{l}\text { Guna menata kembali } \\
\text { lembaga maka perlu adanya } \\
\text { pendekatan lebih besar dari } \\
\text { sekedar pengukuran } \\
\text { tradisional }\end{array}$ \\
\hline
\end{tabular}

Secara umum pengelolaan pendidikan di MAN 2 Mataram meliputi (1) pengelolaan kurikulum, (2) pengelolaan peserta didik, (3) pengelolaan tenaga kependidikan, (4) pengelolaan sarana prasarana pendidikan, (5) pengelolaan keuangan pendidikan, (6) pengelolaan hubungan dengan masyarakat, dan (7) pengawasan pendidikan. Proses restrukturisasi diperlukan suatu pendekatan yang direkomendasi dalam empat langkah pendekatan proses restrukturisasi, yaitu (1) menetapkan konteks dan mengembangkan pedoman dasar dan tujuan artinya kepala sekolah yang merencanakan untuk merestrukturisasi administrasi lembaga dengan menentukan konteks dan mengembangkan dasar dan tujuan yang akan digunakan sebagai dasar dalam membuat keputusan, (2) mengidentifikasi dan memprioritaskan peluang yang bermakna untuk meningkatkan dan mewujudkan kemenangan dengan cepat, (3) merencanakan dan mengenalkan program implementasi, dan (4) meningkatkan kesepakatan pada model bisnis. Dalam menata ulang lembaga pendidikan diperlukan langkah berupa pemikiran kembali dalam hal struktur administrasi akademik, dan untuk mencapai perubahan sistemik memerlukan pendekatan lebih dari sekedar pengukuran tradisional lainnya.

\section{Tujuan dan Sasaran}

Pada hakekatnya kegiatan manajemen kemitraan dalam meraih keunggulan bersaing yang diterapkan di MAN 2 Mataram meliputi tiga hal utama, yaitu mengelola sumberdaya manusia, menggelola organisasi dan mengelola perubahan. 
Pengelolaan sumberdaya manusia di MAN 2 Mataram meliputi memotivasi staf mengambil dan menerapkan keputusan, mengelola pertemuan, menerima, menilai dan mengembangkan staf, mengelola konflik perselisihan pendapat, dan mengelola dirinya sendiri. Pengelolaan organisasi di MAN 2 Mataram meliputi kegiatan mengelola organisasi, mengelola tim, mengelola kurikulum, mengelola kualitas kesehatan dan keselamatan, mengelola sumber-sumber belajar, dan mengelola lingkungan. Sedangkan pengelolaan perubaban di MAN 2 Mataram, meliputi mengelola perubahan yang terjadi, menentukan pendekatan, mengelola perubahan yang sistematis, dan mengelola masa transisi perubahan. ${ }^{21}$

Manajemen kemitraan di MAN 2 Mataram pada hakikatnya berkenaan dengan cara-cara pengelolaan suatu lembaga agar supaya lembaga tersebut efisien dan efiktif. Suatu lembaga akan efisien apabila investasi yang ditanamkan di dalam lembaga tersebut sesuai atau memberikan profit sebagaimana yang diharapkan. Selanjutnya suatu institusi akan efektif apabila pengelolaannya menggunakan prinsip-prinsip yang tepat dan benar sehingga berbagai kegiatan di dalam lembaga tersebut dapat mencapai tujuan sebagaimana yang telah direncanakan. Manajemen kemitraan di MAN 2 Mataram merupakan suatu proses yang unik yang terdiri dari aktivitas perencanaan, pengorganisasian, pelaksanaan, dan pengendalian, serta dilakukan untuk menentukan dan mencapai tujuan dengan memanfaatkan sumber daya manusia dan sumber daya lainnya ${ }^{22}$.

Sherry Keith dan Robert H.Girling menyatakan bahwa dalam pengelolaan pendidikan perlu difahami konsep manajemen partisipatoris yang menitik beratkan kepada keterlibatan anggota/pegawai secara tetap dan signifikan dalam pengambilan keputusan organisasi. Keterlibatan anggota/pegawai dimulai dari penetapan tujuan, penyelesaian permasalahan, dan pengambilan keputusan yang mempengaruhi organisasi secara keseluruhan seiring dengan pekerjaan individu mereka, penetapan dan peningkatan standar kinerja, serta mencapai target organisasi dalam memenuhi kebutuhan pelanggan.

21 Observasi. Tujuan dan Sasaran Kemitraan di MAN 2 Mataram. 9 Juli 2017

22 Wawancara. Tujuan dan Sasaran Kemitraan di MAN 2 Mataram. KM.9 Juli 2017 
Tugas utama manajemen modern yaitu (1) mengelola kerja dan organisasi. Organisasi kecil atau besar, pribadi atau publik, manajemen harus memastikan bahwa organisasi berjalan dan dikelola. Semua bagian dari organisasi harus dikelola termasuk organisasinya sendiri, (2) mengelola manusia. Manajemen mencapai tujuannya dengan mendayagunakan sumber daya manusia. Walaupun pengertian tersebut terlalu disederhanakan, tetapi hal tersebut menunjukkan bahwa tiada organisasi tanpa manusia. Oleh karena itu pengelola harus mengetahui bagaimana memotivasi, memimpin dan berkomunikasi, dan (3) mengelola produksi dan organisasi. Produksi mengacu pada organisasi manufaktur yang output-nya nyata, sedangkan operasi juga merupakan aktivitas produksi tetapi output-nya. bisa berupa barang dan dapat pula berupa jasa.

Tabel. 5

Tujuan dan Sasaran Kemitraan di MAN 2 Mataram $^{23}$

\begin{tabular}{|l|l|l|c|}
\hline NO & \multicolumn{1}{|c|}{ Uraian } & \multicolumn{1}{|c|}{ Bentuk } & Ket \\
\hline 1 & Mengelola kerja dan organisasi & $\begin{array}{l}\text { Manajemen harus } \\
\text { memastikan organisasi } \\
\text { berjalan dan dikelola }\end{array}$ & \\
\hline 2 & Mengelola manusia & $\begin{array}{l}\text { Manajemen mencapai } \\
\text { tujuan dengan } \\
\text { mendayagunakan sumber } \\
\text { daya manusia }\end{array}$ & \\
\hline 3 & Mengelola produksi dan organisasi & $\begin{array}{l}\text { Produksi mengacu pada } \\
\text { organisasi yang out putnya } \\
\text { nyata termasuk produksi } \\
\text { jasa pendidikan }\end{array}$ & \\
\hline
\end{tabular}

Titik pusat bagi tujuan organisasi dan prestasi organisasi. Kualitas dalam produk tidak mungkin ada tanpa kualitas di dalam proses. Kualitas dalam proses tidak mungkin ada tanpa organisasi yang tepat. Organisasi inilah yang menentukan kualitas keseluruhan manajemen. Meskipun demikian organisasi yang tepat tidak ada artinya tanpa kepemimpinan yang memadai. Komitmen yang kuat dari bawah ke atas yang merupakan pilar pendukung bagi pilar-pilar yang lain. Dengan demikian kelima pilar tersebut tidak dapat dipisahkan. Adapun konstruksi yang dilakukan oleh MAN 2 Mataram dengan

${ }^{23}$ Observasi. Tujuan dan Sasaran Kemitraan di MAN 2 Mataram. 9 Juli 2017 
menyusun model tata letak atau model dari sebuah bangunan fisik sekolah dan tata ruang di masing-masing ruangan yang ada di sekolah tersebut seperti mengatur ruangan untuk kepala sekolah, para guru, para pegawai TU, para siswa. Sehingga sekolah tersebut teratur dan indah untuk dilihat dan nyaman untuk tempat bagi siswa belajar. ${ }^{24}$

Konflik dalam kemitraan diperlukan adanya kolaborasi di mana masingmasing pihak berkeinginan untuk saling memenuhi kepentingan semuanya. Kolaborasi dimungkinkan terjadi, jika terjadi kompromi yaitu adanya kesediaan para pihak yang berkonflik untuk saling membagi beban dan bermanfaat. Kolaborasi menjadi efektif, jika dilakukan dengan cara-cara yang akomodatif. Penandatanganan bersama Nota Kesepahaman atau Memorandum Of Understanding $(\mathrm{MoU})$ untuk berbagai program yang akan dikembangkan bersama. Bersamaan dengan penawaran penandatanganan bersama MoU tersebut, khususnya dengan lembaga TVRI NTB, MAN 2 Mataram mengajukan juga proposal untuk tawaran sebuah bentuk program siaran. Seiring dengan berjalannya pembicaraan untuk tawaran program siaran dengan materi dari MAN 2 Mataram, pihak TVRI -NTB datang ke madrasah meminta para ustadz atau guru di MAN 2 Mataram untuk mengisi materi dalam mata acara Cermin yang disiarkan pada bagian pembuka siaran TVRI NTB pada setiap sore. Dan Kami sangat menyambut baik program kerja sama itu dan menyerahkan secara teknis pelaksanaan kerja sama kepada Wakil Kepala Bidang Humas. Sebagaimana diketahui bahwa Tujuan dan Sasaran adalah segala sesuatu yang menjadi visi misi dari sebuah organisasi atau lembaga, serta apa yang menjadi obyek dari sebuah tujuan.

\section{Kesimpulan}

Model strategi kemitraan dapat ditnjau dari proses, visualisasi, konstruksi, tujuan serta sasaran terdiri dari;

1. Proses Kemitraan di MAN 2 Mataram terdiri dari; (1) bertbasis keunggulan dengan pola kerjasama dengan pelanggan untuk saling menguntungkan, (2) Kualitas kerjasama dengan pemasok agar tercapai tujuan khusus, (3) Berdaya

${ }^{24}$ Wawancara. Tujuan dan Sasaran Kemitraan di MAN 2 Mataram. KMT. 9 Juli 2017 
saiang, kemitraan dalam pemanfaatan sumberdaya mitra, (4) berkelanjutan dalam pengembangan kepercayaan.

2. Visualisasi terdiri dari; (1) menumbuhkan pemahaman dan pengamalan nilai-nilai ajaran agama bagi warga madrasah dalam bentuk spiritualitas, nilai moralitas, dan nilai sosial, (2) menguasai ilmu pengetahuan dan teknologi berlandaskan iman dan taqwa dengan bentuk menguasai Ilmu Pengetahuan Alam (IPA), Ilmu Pengetahuan Sosial (IPS), dan Bahasa Asing seperti Bahasa Arab dan Bahasa Inggris serta Ilmu-ilmu Agama baik yang berkaitan dengan Fiqih, Tauhid, dan Sejarah Kebudayaan Islam, (3) membudayakan lingkungan belajar dan bekerja yang berorientasi pada perubahan membentuk warga madrasah yang berdaya saing dalam era global; seperti malakukan mitra kerja dengan pihak eksternal seperti pihak Swasta maupun negeri, (4) mewujudkan madrasah yang mampu memberikan pelayanan terbaik kepada semua lapisan masyarakat dengan bentuk memberikan rasa kenyamanan bagi warga sekitar madrasah baik yang berupa instansi maupun non instansi.

3. Konstruksi melalui; (1) Menetapkan konteks, mengembangkan pedoman dasar dan tujuan, merencanakan konstruksi administrasi lembaga serta mementukan konteks dan mengembangkan dasar juga tujuan yang akan digunakan dalam pengambilan keputusan, (2) Mengidentifikasi dan memprioritaskan peluang dengan meningkatkan dan mewujudkan kemenangan dengan cepat, (3) Merencanakan dan mengenalkan program dengan membuat rencana dan bagaimana mengenalkan program kepada para mitra, (4) Meningkatkan kesepakatan pada model bisnis, guna menata kembali lembaga maka perlu adanya pendekatan lebih besar dari sekedar pengukuran tradisional

4. Tujuan dan sasaran terdiri dari (1) Mengelola kerja dan organisasi, (2) Mengelola manusia untuk mencapai tujuan dengan mendayagunakan sumber daya manusia, (3) Mengelola produksi dan organisasi mengacu pada organisasi yang out putnya nyata termasuk produksi jasa pendidikan. 


\section{Daftara Pustaka}

Abdul Munir Mulkhan, Nalar Spiritual Pendidikan : Solusi Problem Filosofis Pendidikan Islam, Yogyakarta: PT Tiara Wacana, 2002.

A.B. Musyafa' Fathoni, Strategi Diferensisai Sebagai Upaya Mewujudkan Layanan Pendidikan Yang Berkualitas, Ponorogo, STAIN Press Ponorogo, 2011.

Al Musanna dan Syamsul Bahri ,Quo Vadis Desentralisasi Pendidikan Di Indonesia Tinjanan Historis, Orientasi dan Reformulasi Desentralisasi Pendidikan, Jurnal Islam Futura, Volume X, No. 2, Februari 2011.

Akdon, Strategic Management For Educational Management Manajemen Strategik Untuk Manajemen Pendidikan), cet. 4, Bandung: Alfabeta, 2011.

Azra, Azyumardi, Pendidikan Islam; Tradisi dan Modernisasi Menuju Milenium Baru, Jakarta, Logos, 1999.

Dan Schendel dan Charles Hofer, Higgins, Pengambilan Keputusan Stratejik. Untuk organisasi public dan Organisasi Non Profit, Jakarta: Grasindo,1985.

Dokumentasi Sejarah Lahirnya MAN 2 Model Mataram, disadur dari Divisi Pengembang Madrasah, pada tanggal 20 Oktober 2016.

Depag, Visi, Misi, dan Strategi Pembinaan Madrasah, Jakarta:Dirjen Kelembagaan Agama Islam, 2004.

George R. Terry, Prinsip-Prisip Manajemen, Alih Bahasa oleh J. Smith, D.F.M, Jakarta: Bumi Aksara, 2014.

Hasbullah, Otonomi Pendidikan, Jakarta: PT Raja Grafindo Persada, 2006.

Hasan Baharun, Desentralisasi Dan Implikasinya Terhadap Pengembangan Sistem Pendidikan Islam dalam Jurnal Ilmu Tarbiyah "At-Tajdid", Vol. 1, No. 2, Juli 2012.

H.A.R Tilaar, Membenabi Pendidikan Nasional, Jakarta: Rineka Cipta, 2002.

Hikmat, Manajemen Pendidikan, Bandung: Pustaka Setia, 2009.

Imam Helianti Kusuma, Manajemen Pendidikan di Era Reformasi, Dalam Jurnal Pendidikan, Vol. 63, Jakarta: BPK Penambur, 2006.

Mada Sutapa, Perspektif Desentralisasi Pendidikan dalam Konteks Desentralisasi Pemerintahan, Jurnal Manajemen Fewidikan, No. 01, Oktober, 2005.

Made Pidarta, Perencanaan Pendidikan Partisipatori Dengan Pendekatan Sistem, Edisi Revisi, Jakarta: Rineka Cipta, 2015.

Muhaimin, Wacana Pengembangan Pendidikan Islam, Yogyakarta: Pustaka Pelajar, 2003.

Nana Rukmana D.W., Strategic Partnering For Educational Management, IKAPI: Alfabeta, 2006.

Rodliyah, Partisipasi Masyarakat Dalam Peangambilan Keputusan dan Perencanaan di Sekolah, Yogjakarta: Pustaka Pelajar, 2013.

37 Palapa: Junal Studi Keislaman dan Ilmu Pendidikan 
S. Ali Jadid

Volume 5 Nomor 2 November $2017 \quad 38$ 
Model Strategi Kemitraan 